\title{
Indoor Thermal Comfort in Modern Mosque of Tropical Climate
}

\author{
Wardah Fatimah Mohammad Yusoff $\odot$ \\ Faculty of Engineering and Built Environment, Universiti Kebangsaan Malaysia. Email: wardahyusoff@ukm.edu.my
}

\begin{abstract} Purpose

The requirement of indoor thermal comfort in building is crucial, including the religious building such as mosque, which accommodates high occupancy level due to the congregational prayer. With this condition, the application of air conditioning system in a mosque is common, especially the modern mosque in hot climate where the layout plan is more complex compared to the vernacular mosque. Hence, the aim of this study is to evaluate whether the modern mosque design is able to provide the required indoor thermal comfort condition in tropical climate.
\end{abstract}

Design/Methodology/Approach

The National University of Malaysia's mosque was selected for the study. Two research methodologies were conducted concurrently, which were the field measurement and the questionnaire survey. The purpose of conducting these two methods was to compare the indoor thermal condition with the actual thermal sensation and satisfaction of the users. Both methods had been executed for four days, and there were 120 respondents who had participated in the survey.

Findings

The findings indicated that most users felt neutral thermal sensation only during the morning hours which was at the indoor operative temperature range of $28.5{ }^{\circ} \mathrm{C}$ to $30.1{ }^{\circ} \mathrm{C}$. Meanwhile in the afternoon and late afternoon hours, where the indoor operative temperature was more than $30^{\circ} \mathrm{C}$, majority of them felt slightly warm. Despite that, they still voted for neutral or satisfied feeling during the afternoon and the late afternoon hours.

\section{Research Limitations/Implications}

The limitations in the study were the field measurement duration which was four days only and the location of the measuring tool which was at the prayer hall of the first floor level.

Originality/Value

The findings of this study can be used as a guidance in providing a modern mosque design that has good response to the tropical climate. This study also helps to embark other investigations in the future by using other methodologies such as numerical simulation and experiment.

Keywords: Mosque, thermal comfort, tropical climate, energy saving, building environment 


\section{INTRODUCTION}

Mosque is one of the religious buildings which is actively used by Muslims in executing the daily prayers. The mosque designs are originally various, depending on the climatic condition where they are situated, as well as the cultural influence (Atmaca \& Gedik, 2020). In the hot arid climate, the vernacular mosque is normally rectangular shape, with a flat roof design (Azmi \& Ibrahim, 2020). Meanwhile, in the Southeast Asia region, where the climatic condition is mainly tropical, the vernacular mosque normally has tiered sloping roof with large overhang. It's layout plan is usually formed by rectangular or square shape, with veranda all around (Ahmad, 2015). Despite the various climatic conditions which result in variety approaches of mosque designs, there is one common approach all around the world, where there is a large prayer area or hall that is oriented towards the Qiblah (the Ka'bah's direction that is located in Makkah). Hence, the vernacular mosque is normally simple and straightforward, with a good climate responsive design.

On the contrary, the design of modern mosque usually has global influence. The modern mosque layout plan is normally more complex than the vernacular mosque. It usually encompasses of many floor levels and additional spaces other than the prayer hall. This is due to the accommodation of activities other than prayer such as religious classes, meeting and social gathering. Though many modern mosques still remain the rectangular shape for the prayer hall, the roof configuration is normally dominated by dome shape instead of flat or tiered sloping roof. Due to the variations in the modern mosque designs, a question arises whether such design variations address the indoor thermal comfort, especially at the prayer hall.

\section{ANTECEDENTS}

Mosque is one of the religious buildings which is actively used by Muslims in executing prayers. This section discusses on the previous studies related to the thermal comfort in tropical climate, as well as focusing on the indoor thermal comfort of mosque.

\section{Thermal Comfort in Tropical Climate}

Tropical climate is the climate that confines within the tropical region, which the latitude line is between the Tropic of Cancer $\left(23.5^{\circ} \mathrm{N}\right.$ latitude) and the Tropic of Capricorn $\left(23.5^{\circ} \mathrm{S}\right.$ latitude). Among the characters of tropical climate are the mean monthly temperature is more than $18{ }^{\circ} \mathrm{C}$, the seasonal variation in temperature is modest where the variation mainly occurs in rainfall and irradiance, and the daily range of maximum and minimum temperature normally exceeds the monthly mean range. In the tropical climate, the seasons are generally determined by the rainfall (Schaik \& Pfannes, 2005). Examples of countries that experience tropical climate are Mexico, Columbia, Ecuador, Brazil, Malaysia, Thailand, Indonesia and Singapore. 
There are many previous studies that discussed on the thermal comfort in tropical climate. Nevertheless, the studies are still considered insufficient when compared to the increasing percentage of people who live in the tropical climate. It is foreseen that in 2050, approximately $50 \%$ of the world population will live in the countries that experience tropical climate (Rodriguez \& D'Alessandro, 2019). The thermal comfort studies in the tropical climate focus on many aspects as factors that influence the thermal comfort inside a building are various such as the orientation, ventilation, material properties, space utilization and incorporation of active and passive strategies (Latha et al., 2015). Among the strategies that aid to achieve thermal comfort in tropical climate are applying building materials that have low thermal diffusivity, thermal conductivity and absorptivity, finishing the external surfaces with light colour and reflective paint (Latha et al., 2015; Farhan et al., 2021; Jayasinghe et al., 2003), using appropriate roof insulation material (Amir et al., 2019), providing shading at the window (Latha et al., 2015; Tjie et al., 2020), as well as applying appropriate façade design such as optimum window-towall ratio and façade insulation (Tong et al., 2021).

There are three types of thermal comfort models namely the static model, the adaptive model and the hybrid model. The static model is developed based on the human heat balance, which considers the heat exchange between the human body and the surrounding environment. The examples of static model are Standard Effective Temperature (SET) and Predicted Mean Vote (PMV). The adaptive model is different from the static model where this model believes that when discomfort occurs, people have the ability to adapt themselves to the environment in restoring the comfort. The adaptation includes the adjustment in the behavior, psychology and physiology aspects. Meanwhile, the hybrid model is the combination of the static and adaptive models. The example of this model is Adaptive Predictive Average Vote (aPMV) (Kiki et al., 2020). Nevertheless, it is important to note that whichever comfort models adopt in the studies, the individual differences must be put into consideration. The examples of individual differences are the gender, age, clothing and activity (Wang et al., 2018).

All these models have been used in the thermal comfort studies of tropical climate. Those studies can be categorized into two namely the outdoor thermal comfort and the indoor thermal comfort. Das et al. (2020) investigated the outdoor thermal comfort of eight sites in the region of tropical climate using Local Climatic Zones (LCZs) approach. Xue and Lau (2016) examined the comfort and health of urban open spaces in Singapore and Hong Kong. The study indicated that controlling the geometry of the urban canopy layout would be effective in achieving outdoor thermal comfort. In addition, Hoseini et al. (2019) also emphasized that vegetation and shading elements able to improve the outdoor thermal comfort in the tropical climate of Malaysia. To date, the studies of indoor thermal comfort in the tropical climate have outnumbered the outdoor thermal comfort studies. Among the studies 
are Mallick (1996), Wong et al. (2002), Wijewardanea and Jayasinghe (2008), Guevara et al. (2021), Chaiyapinunt and Khamporn (2021) and many others.

Wijewardanea and Jayasinghe (2008) indicated that people in the tropical climate who performed light factory works could tolerate the temperature of $30{ }^{\circ} \mathrm{C}$. This temperature could be increased up to $34{ }^{\circ} \mathrm{C}$ with the presence of higher air velocity which was $0.6 \mathrm{~m} / \mathrm{s}$. The great tolerance to high temperature by people in tropical climate was also agreed by Mallick (1996) and Wong et al. (2002). Mallick (1996) investigated the indoor thermal comfort of occupants in Bangladesh's urban housing, while Wong et al. (2002) examined the thermal comfort in Singapore's public housing. Wong et al. (2002) also added that people won't be passive when they were in an uncomfortable environment as they would take adaptive measures to restore their comfort. Among their actions were adjusting the clothes, changing the activities, bathing and many others.

On the contrary, Guevara et al. (2021) derived lower neutral temperature for the thermal comfort of students in the university classrooms that were located in the three cities of Equador. The derived neutral temperatures were $21.8^{\circ} \mathrm{C}$ for highland region, $26.3^{\circ} \mathrm{C}$ for coastal region and $26.9^{\circ} \mathrm{C}$ for rainforest region. The study also found that students who already adapted to the warm environment were sensitive to the air movement. The slight change in the air movement caused different thermal comfort sensation to them. Nevertheless, the study also summarized that the students preferred colder environment to warmer one, despites the differences of the regions. Chaiyapinunt and Khamporn (2021) investigated the thermal comfort of people in tropical climate who were sitting near the glass windows. The study found that the thermal discomfort did not rely on the distance of people from the window, but it was determined by the magnitude and direction of the solar incidence on the people.

\section{Indoor Thermal Comfort of Mosque}

The utilization frequency of a mosque is different from other building typologies, as it occupies high capacity of users at certain hours due to the congregational prayers. In Islam, there are five times of prayers a day, and a weekly Jumuah prayer (a prayer that is executed in the midday of Friday) which are conducted congregationally. Hence, it is pivotal to ensure the thermal comfort condition inside a mosque is achieved (Atmaca and Gedik, 2020; Manaf et al., 2020; Yüksel et al., 2020; Azmi and Ibrahim, 2020). Due to this necessity, there are many mosques nowadays that incorporate cooling or heating systems (depending on the climate) at the prayer halls to enhance the indoor thermal comfort condition. This action has definitely caused the increase of energy usage, thus resulting in many other negative impacts to the environment and economical aspects (Azmi \& Ibrahim, 2020). 
There are many parameters that affect the indoor thermal performance of a mosque, namely the site surrounding, orientation, form and shape, apertures and building materials. The uniqueness of mosque compared to the other building typologies is that it is normally designed to be symmetrical, and oriented towards the Qiblah direction (as aforementioned), regardless the sun path and the site condition (Azmi \& Ibrahim, 2020). In addition, the principles of congregational prayer also influence the shape of the mosque, particularly the prayer hall. This area is normally rectangular shape and designed to be barrier-free (Azmi \& Kandar, 2019).

Achieving an indoor thermal comfort via passive design in the tropical climate is a challenge. This is due to the climatic condition that has constantly high air temperature and relative humidity throughout the year. The vernacular architecture of tropical climate has indicated on certain criteria to be fulfilled in achieving a good climate responsive design. Among the criteria are the minimization of wall exposure to the direct solar radiation via the incorporation of large roof overhang, the utilization of low thermal capacity materials such as bamboo and timber, and the provision of abundant openings in allowing good air flow. Nevertheless, these criteria are less considered in the modern mosque design due to the global influence.

Therefore, the objective of this study is to investigate the selected modern mosque, and analyze whether the design addresses the indoor thermal comfort condition of the users. The findings from this study is useful to embark other investigations in relation to the indoor thermal comfort of modern mosque design. The study focuses on the prayer hall as it is the area that serves the main purpose of a mosque. Though there are already many previous studies on indoor thermal comfort of mosques in various climates (Abdullah et al., 2016; Munir et al., 2020; Al-ajmi, 2010; AlHomoud et al., 2009; Atmaca and Gedik, 2020; Hussin et al., 2015; Manaf et al., 2020; Saeed, 1996; Yüksel et al., 2020; Yusoff, 2020a), the empirical investigation related to the naturally ventilated modern mosque in tropical climatic condition is still lacking. Azmi and Ibrahim (2020) who conducted a review on the thermal performance of mosque also stated that the studies within the tropical climate are still insufficient.

Yusoff (2020a) and Yusoff (2020b) had conducted studies on the thermal comfort, as well as the natural ventilation of a mosque located in the tropical climate of Malaysia. However, the investigations were executed on a vernacular mosque instead of a modern mosque. Meanwhile, Munir et al. (2020) compared the thermal sensation and satisfaction of people who used the timber and concrete mosques in tropical climate. Nonetheless, the actual indoor thermal condition of the mosques had not been measured. Hussin et al. (2015) investigated the reliability of PMV thermal comfort model at a modern mosque in the tropical climate of Malaysia. However, the investigation was specified to an indoor condition that applied air-conditioning system. Similarly, Al-Hamoud et al. (2009) also investigated thermal comfort condition in air-conditioned mosque 
that is located in the eastern region of Saudi Arabia, where the climate is hot and humid. There are also other few studies that investigated thermal comfort of mosques in hot and humid climate, but there is no empirical finding presented. The examples are the studies by Abdullah et al. (2016), who focused on developing a theoretical framework, and Manaf et al. (2020) who provided discussion based on literature studies.

The study presented in this paper is considered as an additional knowledge to the related field, especially for the tropical climate. The findings of this study able to assist the mosque designers to produce a modern mosque design that provides a comfortable indoor thermal environment, as well as having a good response to the tropical climate. The scope of the study is the indoor thermal comfort at the prayer hall of a modern mosque in Malaysia. The selected case study for the modern mosque is National University of Malaysia (UKM)'s mosque. However, there are limitations in the study which are the field measurement duration and the location of the measuring tool. The field measurement was executed for four days only due to the limitation in the availability of the measuring tool. Meanwhile, the location of the measuring tool was at the prayer hall of the first floor level instead of ground floor level. The first floor level was chosen due to the consideration of minimizing the interruption to the congregational prayers, which are usually executed at the ground floor prayer hall. Though such limitations occurred, the findings of this study are still reliable and valuable for the additional knowledge in this field. In addition, this study is an initial stage that will embark other investigations in the future by using other methodologies such as numerical simulation and experiment.

\section{MATERIAL AND METHODS}

There are two stages conducted in this study which the first stage involves the understanding of the UKM's mosque design via the document analyses and observation. Literature studies were conducted on the documents related to the mosque such as the vernacular and modern mosque designs and characteristics, the standards and regulations, as well as information regarding the UKM's mosque. Meanwhile, the layout plans of the UKM's mosque were obtained from the UKM's Infrastructure Office. The observation of the UKM's mosque design was also executed to enhance further the understanding of the information derived from the document analyses. Meanwhile, the second stage involves the field measurement and the questionnaire survey in investigating the indoor thermal comfort condition inside the mosque. The purpose of field measurement is to record the environmental condition of the indoor spaces of the mosque, while the questionnaire survey is essential to derive the thermal comfort sensation and satisfaction of the users. The output from these two stages were compared and analyzed in determining whether the design of UKM's mosque addresses the indoor thermal comfort for the tropical climate of 
Malaysia. The summary of methods conducted in this study is depicted in Figure 1.

Figure 1. The methods conducted in the study.

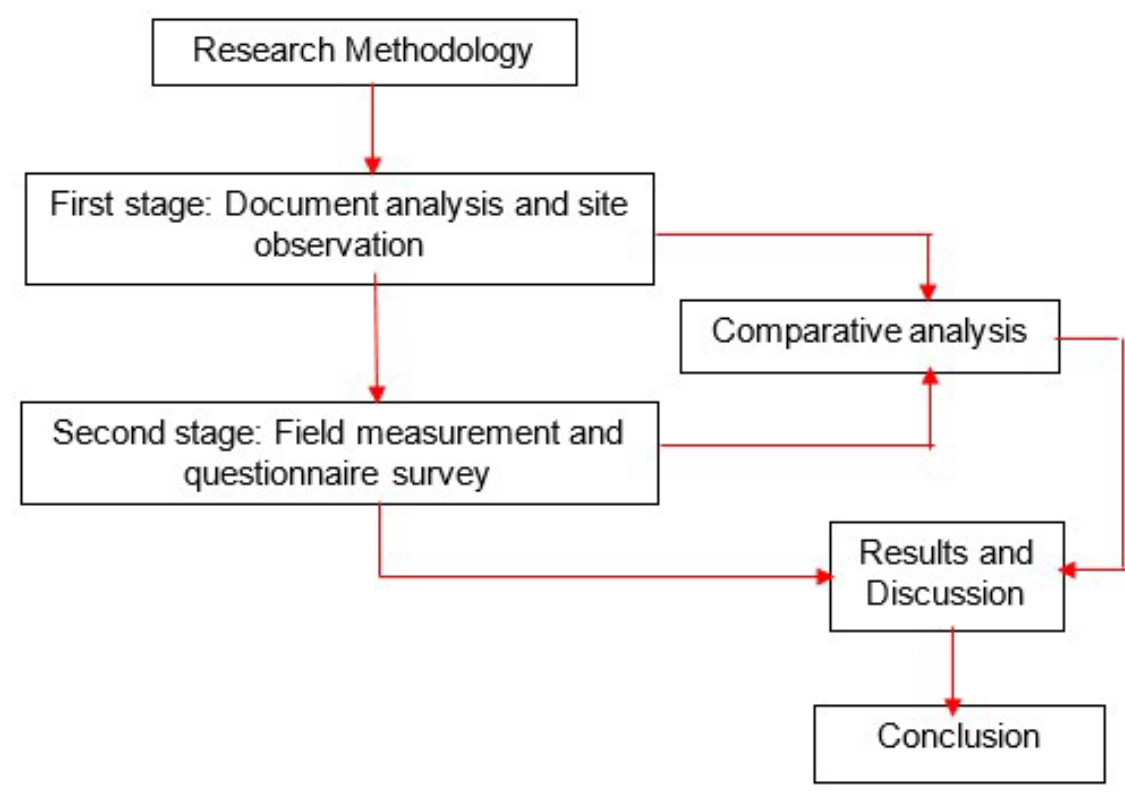

The field measurement and the questionnaire survey were conducted concurrently for four days in April 2019, from 9 am till 4 pm. These two methods had to be conducted simultaneously in comparing the indoor environmental data with the thermal sensation and satisfaction felt by the users. Therefore, it helps to understand the thermal comfort range for the mosque users in the tropical climate, as well as whether the design of the selected mosque provides the required indoor thermal comfort condition. The short duration for the investigation is due to the limitation in the availability of the measuring tool. For this initial investigation, the study also focuses on the daytime only. The evaluation of indoor thermal condition during the nighttime, as well as throughout the year will be conducted in the future research.

\section{Selected Building for Field Measurement: National University of Malaysia's Mosque}

The modern mosque selected for this study is a high institution mosque, belonged to the National University of Malaysia (UKM). Though it is belonged to an institution, the mosque is also used by the community within its proximity due to its location, which is adjacent to the main road. UKM was developed in 1970, where the architectural approach of its buildings during the early years was in line with the architectural movement for the period of 1950s to 1970s in Malaysia. During this period, two architectural design principles dominated namely the functionalist-regionalism and organic-regionalism. The UKM's buildings were designed to follow the principle of functionalism, where it was initially employed by Le Corbusier who also emphasized on the expression of materials, particularly the concrete. This principle believes 
in the functionalist and aesthetic architecture machine, where building is considered as a device that serves as a climate filter to produce a comfortable indoor environment for the human activities (Rasdi \& Mursib, 2004).

This principle is also applicable to the UKM's mosque which was constructed in 1979. Hence, the mosque was selected due to its modern design, where the architectural approach was influenced by the global movement during the period of its construction. Similar to the other UKM's buildings during the early development, the mosque showcases the bare building materials such as concrete and brick. In addition, the mosque design is also dominated by angular geometric shapes, and its facades are also in monochrome colour (Figure 2). These design approaches are synonym with the brutalist architecture characteristics. In addition, the mosque also features variations of egg crate concrete screens in its design, which serve as a tropical adaptation, besides providing a modern aesthetic look. The mosque also has verandas all around, which resemble the vernacular mosque design. With those design approaches, the UKM's mosque is expected to have a good response to the tropical climate of Malaysia, and consequently providing a comfortable indoor thermal environment. However, the actual performance of the mosque with regards to its architectural approach, is still need to be evaluated. Hence, investigation was executed on the UKM's mosque with the intention to examine whether the design implemented is able to achieve the required comfortable indoor thermal environment.

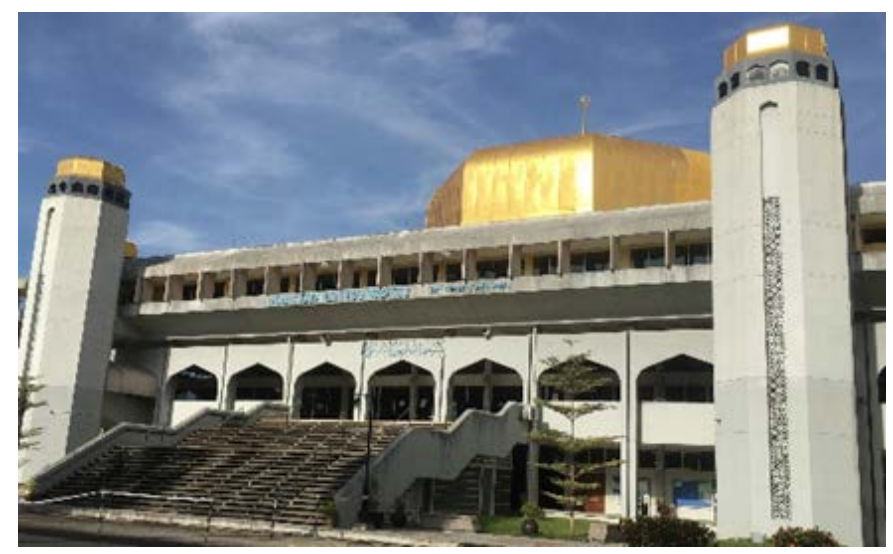

Figure 2. The National University of Malaysia's mosque.

The mosque, which is situated at the main entrance of UKM, was built on a land plot area of 2 hectares. There are six gazebos and approximately 300 car parks that surround the mosque. The basic layout plan of the mosque is rectangular shape. There are verandahs and minarets at the three sides of its facades. It consists of three storeys, with the total gross floor area of approximately 25,713 square meter. With that breadth, the mosque is able to accommodate 5000 people at one time. The ground floor encompasses a prayer hall, two ablution areas (male and female ablution areas), two toilets (male and female toilets), an administration 
office, three seminar rooms, a meeting room, a room for imam (a person who leads the prayer) and a mortuary (Figure 3a). The first floor also consists of a prayer hall, a resource centre and a guest room (Figure $3 \mathrm{~b}$ ), while the second floor, which is the top most floor accommodates a female prayer hall, a studio room, and two ablution areas (Figure 3c). From Figure 3, it can be seen that the centre of the prayer hall at the ground floor area has the height of triple volume, and it is covered by a dome. The prayer areas at the ground, first and second floor levels are shown in Figure 4

Figure 3. The floor plans of the (a) ground floor level, (b) first floor level, and (c) second floor level. The grey colour indicates the prayer areas.

Figure 4. The prayer areas at the (a) ground floor level, (b) first and second floor levels.

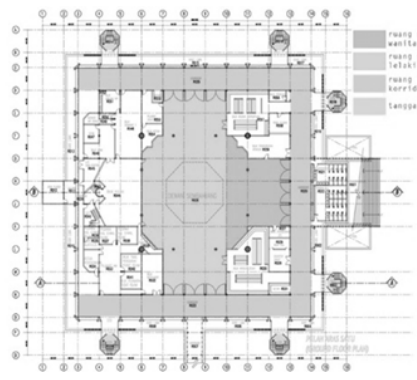

(a)

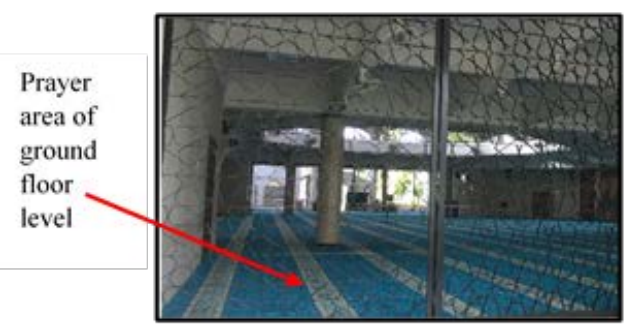

(a)

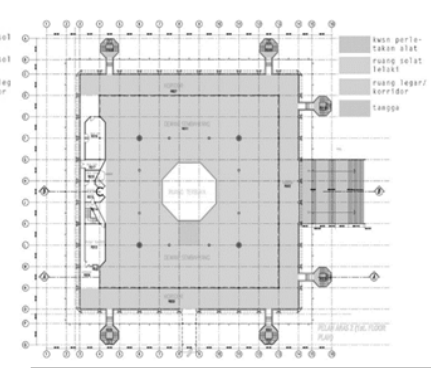

(b)

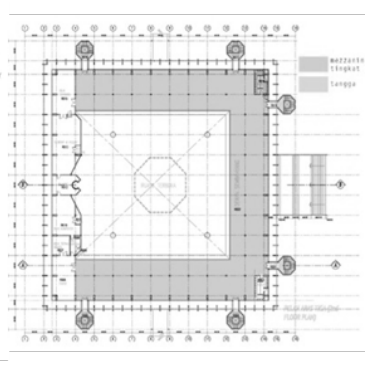

(c)

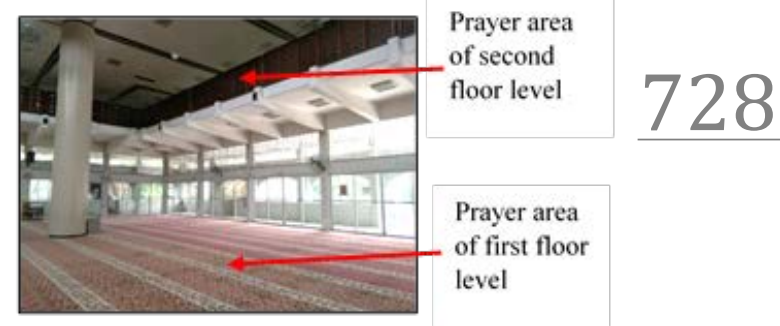

(b)

Though the ground and first floor prayer areas are surrounded by verandas, it is found from the observation that the penetration of daylight is greater at the first floor level. This is due to the presence of glass walls all around, as well as the fixed glass clerestory windows at the dome which allow the daylight penetration. The void beneath the dome area also allows the daylight that enters via the clerestory windows to reach every floor level (Figure 5). However, the daylight amount at the ground floor is lesser than the first floor due to greater distance between the ground floor and the clerestory windows compared to the first floor. In addition, the size of the void at the ground floor is also smaller compared to the first floor level. The ventilation mode applied at the UKM's mosque is hybrid ventilation, which uses the natural ventilation and the mechanical fans. At the first floor level, there are decorative openings placed on top of the glass walls which allow for natural cross ventilation to occur. In addition, there are also glass sliding doors which can be opened to allow for air exchange between the indoor and outdoor (Figure $5)$. 


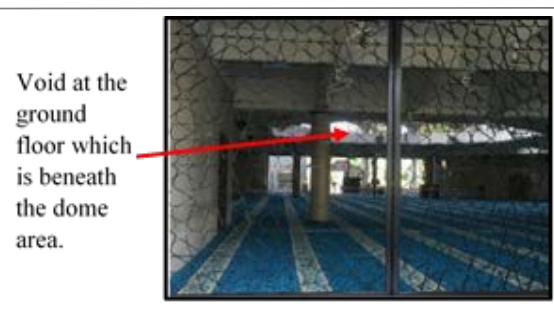

(a)

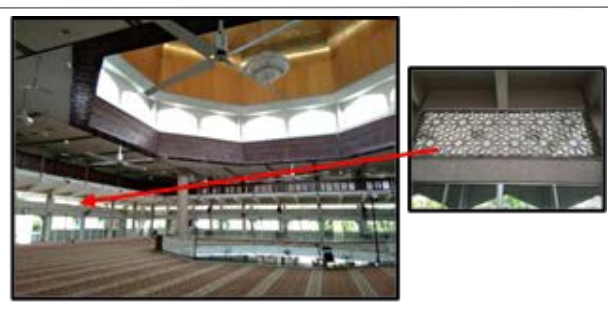

(b)

As aforementioned, there are verandas that surround the prayer areas. Besides being as pathways, the verandas at the ground and first floor levels also function in preventing the penetration of direct solar radiation and rainwater into the prayer areas, especially during the downpour (Figure 6). In the tropical climate, this approach is common for buildings that have good climate responsive design, due to the presence of high solar radiation and precipitation throughout the year.

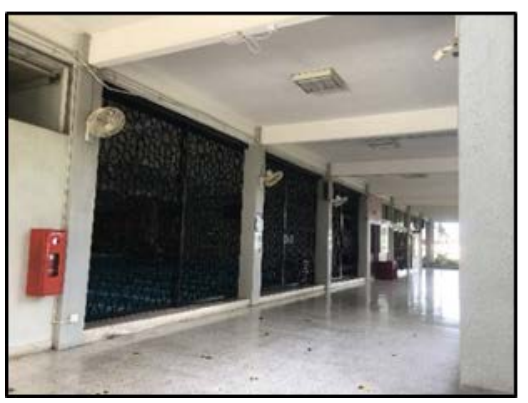

(a)

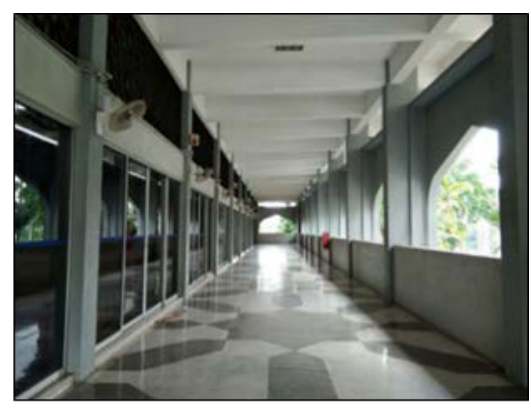

(b)

\section{Field Measurement}

The field measurement was conducted using Delta Log 10, which is capable of recording the data of air temperature, mean radiant temperature, relative humidity and air velocity. Due to the availability of only one Delta Log 10 at the time of measurement, the best location was selected by following the recommendation in ANSI/ASHRAE Standard 55-2017 (ASHRAE, 2017) for the thermal comfort measurement. In addition, the placement of the measuring tool also took into consideration the possibility of having the least interruption to the users' activities especially the congregational prayers. With those considerations, the first floor prayer hall was selected instead of the ground and second floor levels. Nevertheless, the measuring tool was placed at the area near to the void which connects all the three floors. The first floor prayer hall was also selected due to the possibility of switching off the mechanical fans during the measurement time, which was impossible to do that for the ground floor area. The main concern of the mosque administration officers during the measurement was the interruption to the users' activities especially those who were conducting the prayers. Hence, the measurement was executed with the possibility of avoiding the disturbance to the users' activities as much as possible.

Figure 5. The prayer areas at the (a) ground floor level, (b) first and second floor levels.

Figure 6. The verandas at (a) the ground floor level, and (b) the first floor level. 
The measurement accuracy of Delta Log 10 is $\pm 2.5 \%$ for the relative humidity, $\pm 0.1{ }^{\circ} \mathrm{C}$ for the mean radiant temperature, $\pm 0.1{ }^{\circ} \mathrm{C}$ for the air temperature and $\pm 0.05 \mathrm{~m} / \mathrm{s}$ for the air velocity. Before conducting the field measurement, the Delta Log 10 was calibrated in ensuring the reliability of the data recorded. The calibration was executed by comparing its reading with the other similar measuring tool within the same indoor environmental condition. The deviation percentages between both measuring tools were calculated and compared.

During the field measurement, the sensors of Delta Log 10 were placed at the height of 1.1 meter from the floor level. This height is recommended by ASHRAE (2017) for both, the seated and standing positions, which are appropriate for the positions of human activities in the mosque. The Delta Log 10 was also placed as close as possible to the centre of the prayer hall, as the exact location of the centre point was hard to achieve due to the presence of void (Figure 7). The data was measured and recorded at the interval of 10 minutes, from 9 am to $4 \mathrm{pm}$. The outdoor environmental data is also essential in evaluating the indoor thermal comfort, as the mosque is naturally ventilated. The outdoor data was derived from the weather station that was located at the roof top of the Faculty of Engineering and Built Environment's building. The faculty's building is also located within the area of UKM, which is approximately $2.2 \mathrm{~km}$ from the UKM's mosque.

Figure 7. The location of the Delta Log 10 at the prayer hall of the first floor level.

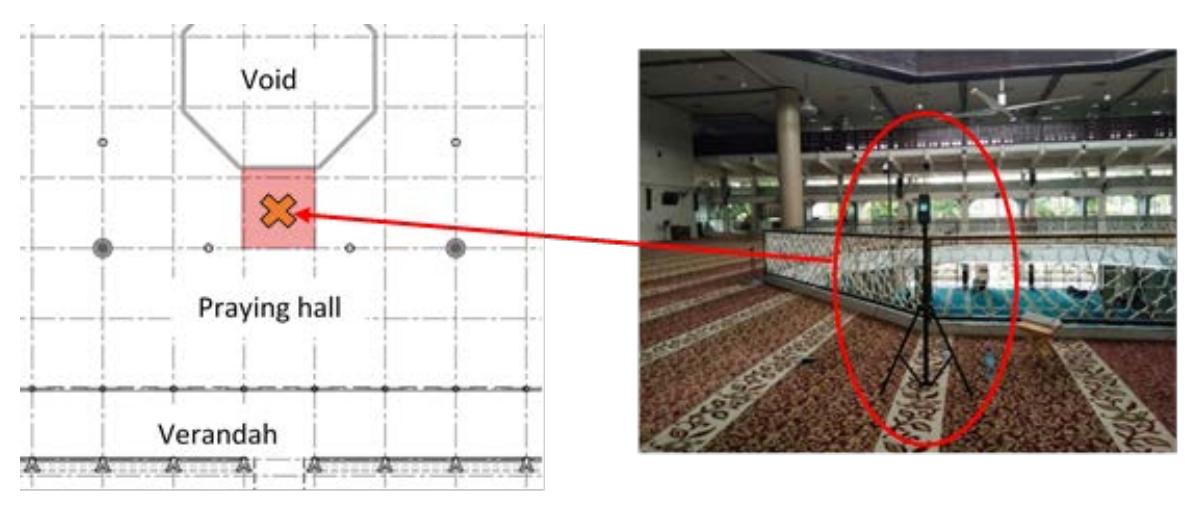

\section{Questionnaire Survey}

The questionnaire survey was conducted concurrently with the field measurement. The survey forms were distributed to 120 respondents throughout the four days of survey. The survey form encompassed of three sections. The first section was specifically for the usage of the researcher in recording the survey time and date of each respondent. The second section documented the personal data of the respondent such as the gender, age, height, weight, nationality, user category, frequency of usage and attire. Meanwhile, the third section examined the thermal sensation, thermal satisfaction and desired thermal condition of the respondents. The thermal sensation and desired thermal condition of the respondents were evaluated using the ASHRAE thermal sensation scale (1: cold, 2: cool, 3: slightly cool, 4: neutral, 5: slightly warm, 6: warm, 7: 
hot) (ASHRAE, 2017). Meanwhile, for the investigation of the respondents' satisfaction, the 7-likert scale (1: very dissatisfied, 2: dissatisfied, 3: slightly dissatisfied, 4: neutral, 5: slightly satisfied, 6: satisfied, 7: very satisfied) was utilized.

The analyses on the respondents' personal data indicated that $66 \%$ of the users were male, while female users were around $34 \%$ only. This is a normal situation as in Islam, the Muslim males are more encouraged to perform the prayer at the mosque compared to Muslim females. Regarding the age group, majority of the respondents were between 13 to 39 years old. This age group was also in accordance with the user category of the survey that indicated on $73 \%$ of student category. This reflects the location of the mosque which is within the institution. Meanwhile, for the height and weight criteria, most respondents were within 161 to $170 \mathrm{~cm}$ and 40 to $60 \mathrm{~kg}$, respectively. Most of the activities conducted in the mosque were the sedentary activities such as seated and standing, which the metabolic rates were within the range of 1.0 to 1.2 MET (ASHRAE, 2017). Meanwhile, for the users' attires, most of the male respondents wore either long sleeve or short sleeve shirt with trousers, while the female respondents wore long dress or 'baju kurung' (a Malay traditional garment) with head cover. Hence, the clothing values for the respondents were within the range of 0.57 to 1 clo (ASHRAE, 2017).

\section{RESULTS AND DISCUSSION}

In this section, the outdoor and indoor environmental data were tabulated in table form, while the users' thermal sensation and satisfaction results were presented in graphs.

\section{Outdoor and Indoor Environmental Data}

Tables 1 and 2 tabulates the hourly average outdoor and indoor environmental data of UKM's mosque for the period of four days in April 2019.

Table 1. The hourly average outdoor environmental data

\begin{tabular}{|c|c|c|c|}
\hline Time & $\begin{array}{c}\text { Hourly Average Outdoor Air } \\
\text { Temperature, } \mathrm{T}_{\text {o }}(\mathrm{deg} \mathrm{C})\end{array}$ & $\begin{array}{c}\text { Hourly Average } \\
\text { Outdoor Wind } \\
\text { Velocity, } \mathrm{V}_{\text {o }}(\mathrm{m} / \mathrm{s})\end{array}$ & $\begin{array}{c}\text { Hourly Average } \\
\text { Outdoor Relative } \\
\text { Humidity, RH (\%) }\end{array}$ \\
\hline $9 \mathrm{am}$ & 27.6 & 0.49 & 94 \\
\hline $10 \mathrm{am}$ & 29.8 & 0.89 & 85 \\
\hline $11 \mathrm{am}$ & 32.2 & 1.08 & 76 \\
\hline $12 \mathrm{pm}$ & 33.0 & 1.18 & 70 \\
\hline $1 \mathrm{pm}$ & 33.5 & 1.27 & 66 \\
\hline $2 \mathrm{pm}$ & 33.7 & 1.39 & 68 \\
\hline $3 \mathrm{pm}$ & 33.1 & 1.66 & 71 \\
\hline $4 \mathrm{pm}$ & 33.6 & 1.64 & \\
\hline
\end{tabular}


Table 2. The hourly average indoor environmental data

\begin{tabular}{|c|c|c|c|c|}
\hline Time & $\begin{array}{c}\text { Hourly Average } \\
\text { Indoor Air } \\
\text { Temperature, } \mathrm{T}_{\mathrm{a}} \\
(\operatorname{deg} \mathrm{C})\end{array}$ & $\begin{array}{c}\text { Hourly Average } \\
\text { Indoor Mean } \\
\text { Radiant } \\
\text { Temperature, } \\
\text { Tmrt }_{\text {(deg C) }}\end{array}$ & $\begin{array}{c}\text { Hourly Average } \\
\text { Indoor Air } \\
\text { Velocity, } \mathrm{V}_{\mathrm{a}} \\
(\mathrm{m} / \mathrm{s})\end{array}$ & $\begin{array}{c}\text { Hourly } \\
\text { Average } \\
\text { Indoor } \\
\text { Relative } \\
\text { Humidity, } \\
\text { RH (\%) }\end{array}$ \\
\hline $9 \mathrm{am}$ & 28.2 & 28.8 & 0.14 & 81 \\
\hline $10 \mathrm{am}$ & 29.0 & 29.2 & 0.10 & 77 \\
\hline $11 \mathrm{am}$ & 30.0 & 30.1 & 0.14 & 71 \\
\hline $12 \mathrm{pm}$ & 30.6 & 30.8 & 0.16 & 64 \\
\hline $1 \mathrm{pm}$ & 31.3 & 31.5 & 0.17 & 60 \\
\hline $2 \mathrm{pm}$ & 31.9 & 31.9 & 0.28 & 59 \\
\hline $3 \mathrm{pm}$ & 32.1 & 32 & 0.35 & 59 \\
\hline $4 \mathrm{pm}$ & 32.3 & 32.1 & 0.32 & 59 \\
\hline
\end{tabular}

The operative indoor air temperature $\left(\mathrm{T}_{\mathrm{op}}\right)$ was used in comparing with the thermal comfort sensation felt by the users. The $\mathrm{T}_{\text {op }}$ data was utilized instead of air temperature $\left(\mathrm{T}_{\mathrm{a}}\right)$ due to the justification that the thermal condition felt by the users were influenced by both parameters, the air temperature and the mean radiant temperature. The $\mathrm{T}_{\text {op }}$ data of Table 3 were derived from the Equation 1, as recommended by (ASHRAE, 2017):

$$
\mathrm{T}_{\mathrm{op}}=\mathrm{A} \mathrm{T}_{\mathrm{a}}+(1-\mathrm{A}) \mathrm{T}_{\mathrm{mrt}}
$$

(Equation 1)

From the equation, the symbol $\mathrm{T}_{\text {op }}$ represents the indoor operative temperature, $\mathrm{T}_{\mathrm{a}}$ denotes the indoor air temperature, $\mathrm{T}_{\text {mrt }}$ symbolizes the mean radiant temperature, while $A$ indicates the value as a function of the average air speed, which was referred to the value recommended in ANSI/ASHRAE Standard 55 (ASHRAE, 2017).

Table 3. The hourly average indoor operative temperature ( $\left.\mathrm{T}_{\mathrm{op}}\right)$

\begin{tabular}{|c|c|}
\hline Time & $\begin{array}{c}\text { Hourly Average Indoor Operative } \\
\text { Temperature, } \mathrm{T}_{\text {op }}(\operatorname{deg} \mathrm{C})\end{array}$ \\
\hline $9 \mathrm{am}$ & 28.5 \\
\hline $10 \mathrm{am}$ & 29.1 \\
\hline $11 \mathrm{am}$ & 30.1 \\
\hline $12 \mathrm{pm}$ & 30.7 \\
\hline $1 \mathrm{pm}$ & 31.4 \\
\hline $2 \mathrm{pm}$ & 31.9 \\
\hline $3 \mathrm{pm}$ & 32.1 \\
\hline $4 \mathrm{pm}$ & 32.2 \\
\hline
\end{tabular}

The hourly average indoor operative temperature was plotted against the predicted indoor comfort temperature (refer to Figure 8) using the Equation 2, which was developed by Toe and Kubota (Toe \& Kubota, 2013).

$$
\mathrm{T}_{\mathrm{c}}=13.8+0.57 \mathrm{~T}_{\mathrm{o}}
$$

(Equation 2)

The equation was developed according to the principle of adaptive thermal comfort (ATC). ATC model is more appropriate for the naturally ventilated building compared to the Predicted Mean Vote (PMV) model due to the constantly changing environment (He, Liu, Kvan, \& Peng, 2017). Moreover, the ATC model has also been used to evaluate thermal comfort in tropical climate by many previous studies (López-Pérez et al., 
2019). The ATC equation is simple and user-friendly where the main influencing parameter to the indoor comfort temperature is the outdoor air temperature, which is represented by $\mathrm{T}_{\mathrm{o}}$ (Carlucci, Bai, de Dear, \& Yang, 2018). $T_{c}$ is the predicted indoor comfort temperature, while value 0.57 is the slope of the function, and 13.8 is the value of $y$-intercept. The value of 0.57 is proportional to the adaptation degree to the tropical climatic condition. The values of 0.57 and 13.8 recommended by Toe and Kubota (2013) were derived from the tropical climate database of ASHRAE RP-884.

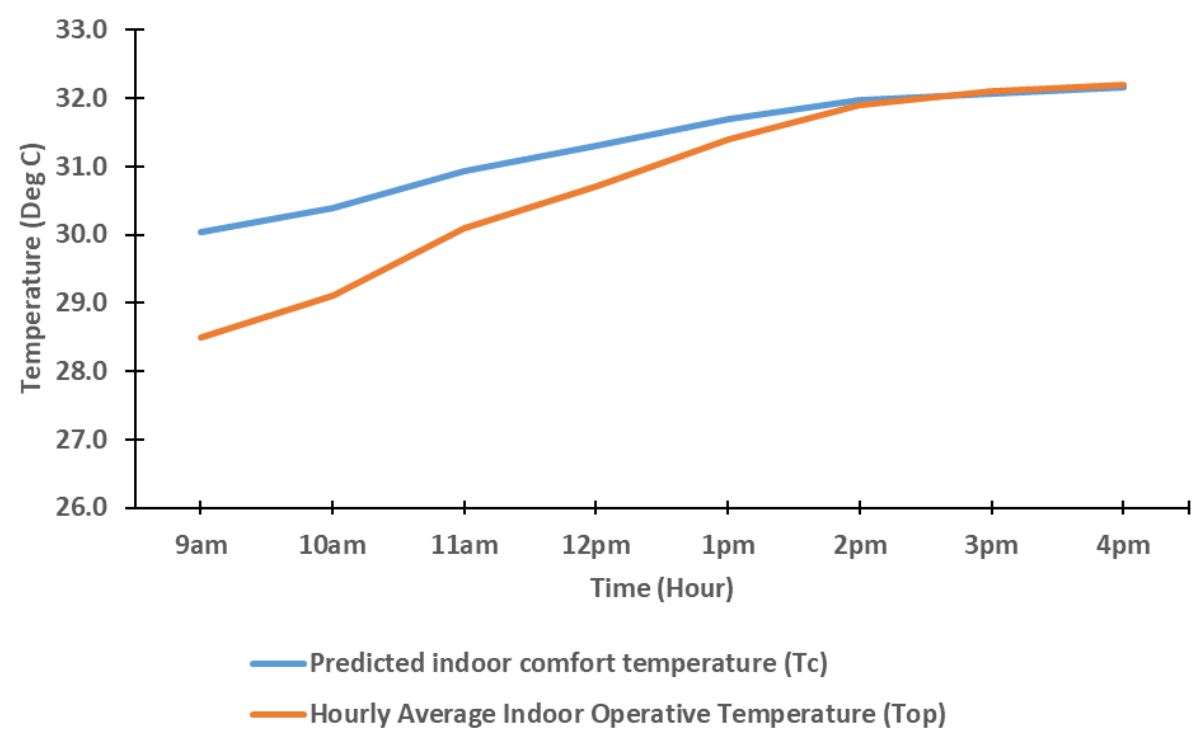

From Figure 8, the $\mathrm{T}_{\text {op }}$ at the prayer hall was lower than the $\mathrm{T}_{\mathrm{c}}$ from $9 \mathrm{am}$ until $2 \mathrm{pm}$, while at $3 \mathrm{pm}$ and $4 \mathrm{pm}$, both temperatures were similar. The results indicate on positive indoor thermal comfort condition at the investigated area. Nevertheless, the filed measurement results need to be compared with the questionnaire survey results to confirm this finding, which this is elaborated in the next section.

\section{Thermal Sensation and Satisfaction of Users}

The thermal sensation and satisfaction of the prayer hall users were derived from the questionnaire survey. Figure 9 depicts the thermal sensation felt by the respondents during the survey. The results indicate that the respondents felt either neutral or slightly cool during the morning hours, while at noon, the thermal sensations were various, from cool to slightly warm. Nevertheless, the slightly warm dominated compared to the other thermal sensations for the afternoon hours. Meanwhile, during the late afternoon hours, which were from 2 pm to 4 $\mathrm{pm}$, the respondents felt neutral to hot, and majority of them felt slightly warm. Figure 9 also shows that the respondents' thermal sensation votes were in agreement with the indoor operative temperature which indicated increment from morning to late afternoon. In addition, the tolerance of respondents towards the indoor operative temperature
Figure 8. The hourly average indoor operative temperature $\left(\mathrm{T}_{\mathrm{op}}\right)$ against the predicted indoor comfort temperature $\left(\mathrm{T}_{\mathrm{c}}\right)$. 
were various, where there were respondents who still felt cool and slightly cool though the operative temperature was more than $30^{\circ} \mathrm{C}$. This is also in correspondence with the study by Caetano et al. (2017) who found that people in tropical climate have great tolerance to the high air temperature.

Figure 9. The thermal sensation of the users

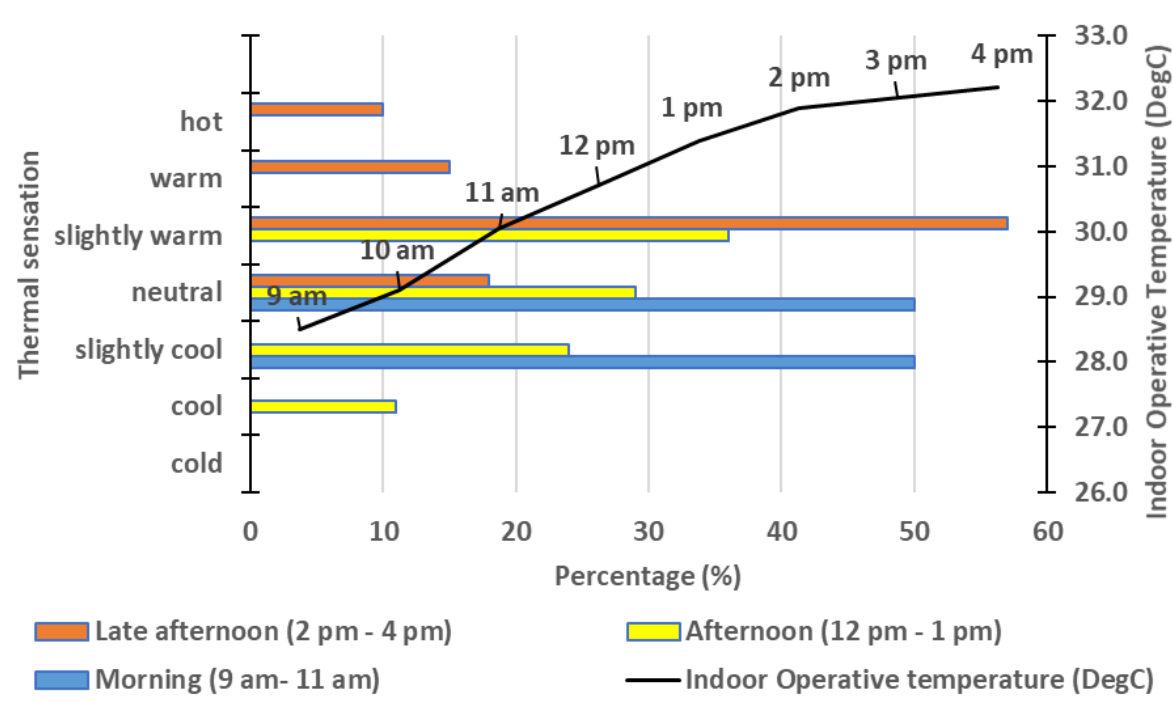

The respondents' thermal satisfactions towards the indoor operative temperature were depicted in Figure 10. The results indicate that during the morning hours where the indoor operative temperature was $28.5^{\circ} \mathrm{C}$ to $30.1{ }^{\circ} \mathrm{C}$, the respondents' thermal satisfactions were within the range of neutral to satisfied. However, the satisfaction feeling was slightly changed during the afternoon hours where there were respondents who felt slightly dissatisfied. Nevertheless, majority of them still felt satisfied with the indoor operative temperature at noon. Meanwhile, the thermal satisfactions of the respondents were various during the late afternoon hours, which range from very dissatisfied to very satisfied. However, most of them felt neutral, which was neither satisfied nor dissatisfied, with the indoor operative temperature. Hence, in comparison to Figure 9, it shows that though many respondents felt slightly warm and above thermal sensation, they still can tolerate it as majority voted for neutral thermal satisfaction. Even, the respondents who opted for slightly satisfied to very satisfied votes were more compared to the votes of slightly dissatisfied to very dissatisfied.

Investigation was also conducted on the desired thermal sensation by the respondents (Figure 11). It is found that many respondents wanted to be in a slightly cooler indoor condition during the morning and afternoon hours though the thermal sensations during the survey were already indicated slightly cool and neutral. Meanwhile, majority desired to have a cooler environment during the late afternoon hours due to the slightly warm condition during the survey. Hence, the results show that though 
in general majority felt satisfied with the indoor operative temperature, they still wished to have a cooler indoor environment.
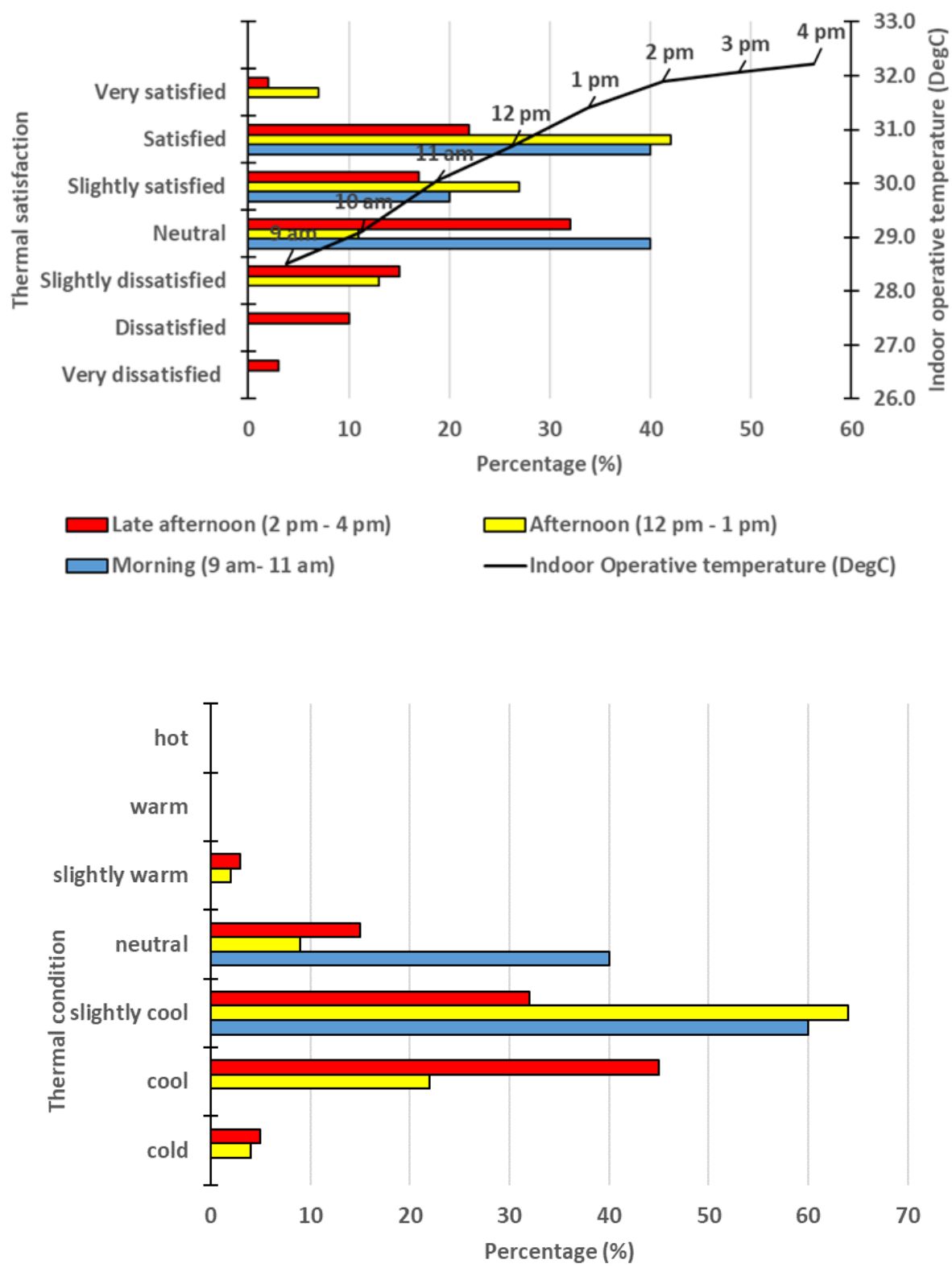

$\square$ Late afternoon (2 pm - 4 pm) $\square$ Afternoon (12 pm - 1 pm) $\square$ Morning (9 am- 11 am)

Based on the results depicted in Figure 9, it is found that most respondents felt slightly warm during afternoon and late afternoon hours. This is in contrast to the results in Figure 8 where the hourly average indoor operative temperature was found to be within the predicted indoor comfort temperature. Nevertheless, the respondents still voted for neutral and satisfied thermal sensations (Figure 10), though if given option, they wanted a cooler indoor thermal condition (Figure 11).

The results of the study also indicate that most respondents felt neutral at the $\mathrm{T}_{\text {op }}$ range of $28.5^{\circ} \mathrm{C}$ to $30.1^{\circ} \mathrm{C}$, which was during the morning hours. The finding is in agreement with the previous studies, which indicated
Figure 10. The thermal satisfaction of the users

Figure 11. The desired thermal condition of the 
that the thermal comfort range for tropical climate was between $26^{\circ} \mathrm{C}$ to $30.4{ }^{\circ} \mathrm{C}$. This range was summarized from the study by Hwang et al. (2006) who indicated $27.4{ }^{\circ} \mathrm{C}$ to $28.8{ }^{\circ} \mathrm{C}$, López-Pérez et al. (2019) who recommended $26.9 \pm 1.3{ }^{\circ} \mathrm{C}$, Djamila et al. (2013) who stated $30.2 \pm 0.2$ ${ }^{\circ} \mathrm{C}$ and Daghigh (2015) who suggested $26{ }^{\circ} \mathrm{C}$ to $28.9^{\circ} \mathrm{C}$. Nevertheless, during the afternoon and late afternoon hours, where the $\mathrm{T}_{\text {op }}$ was more than $30{ }^{\circ} \mathrm{C}\left(30.7{ }^{\circ} \mathrm{C}\right.$ to $\left.32.2^{\circ} \mathrm{C}\right)$, there were still respondents who felt neutral.

The warm thermal sensation during the afternoon and late afternoon hours is due to the utilization of high thermal mass materials such as concrete and bricks. In contrast to the vernacular mosque in Southeast Asia which utilizes timber, the high thermal mass material is able to store more heat, which later is released into the indoor area. However, for the modern mosque which normally has high volume area, the usage of timber as main building material may not be practical. Hence, the combination of high and low thermal mass materials might be an option in improving the indoor thermal condition (Azmi \& Ibrahim, 2020).

In addition, the indoor thermal condition of the UKM's mosque becomes discomfort throughout the day due to the presence of fixed glass clerestory windows at the dome area. Though these windows allow the daylight penetration, there is also heat received from the direct solar radiation especially when the sun altitude is high. Moreover, the fixed glass clerestory windows at the dome also prohibit the stack effect ventilation to occur. The provision of openings at the dome area may enhance the natural ventilation by allowing the stack effect ventilation to occur, and consequently improve the indoor thermal condition (Faghih and Bahadori, 2011; Gagliano et al., 2012).

Nevertheless, the enhancement of indoor air velocity inside the mosque may also improve the indoor thermal comfort. The data recorded during the measurement indicated the air velocity values of lower than $0.5 \mathrm{~m} / \mathrm{s}$ at all times. Based on the findings from the previous studies, it is found that the thermal comfort range can be escalated with the increase of air velocity (Cândido et al., 2011; López-Pérez et al., 2019). The recommended air velocity for the thermal comfort in tropical climate is within the range of $0.13 \pm 0.04 \mathrm{~m} / \mathrm{s}$ for neutral temperature of $26.9 \pm 1.3$ ${ }^{\circ} \mathrm{C}$ (López-Pérez et al., 2019), $0.4 \mathrm{~m} / \mathrm{s}$ for $24{ }^{\circ} \mathrm{C}$ to $27{ }^{\circ} \mathrm{C}, 0.41 \mathrm{~m} / \mathrm{s}$ to 0.8 $\mathrm{m} / \mathrm{s}$ for $27^{\circ} \mathrm{C}$ to $29^{\circ} \mathrm{C}$, and more than $0.81 \mathrm{~m} / \mathrm{s}$ for $29^{\circ} \mathrm{C}$ to $31^{\circ} \mathrm{C}$ (Cândido et al.,2011). Hence, the recorded indoor air velocity at the prayer hall is insufficient to achieve thermal comfort due to the $\mathrm{T}_{\mathrm{op}}$ values of more than $28^{\circ} \mathrm{C}$.

\section{CONCLUSION}

In summary, though the comparison between the indoor operative temperature and the predicted indoor comfort temperature indicated that the mosque's prayer hall was within a comfort indoor environment, the respondents felt neutral thermal sensation during the morning hours only. Nevertheless, majority of the respondents still voted for neutral or 
satisfied feeling despite the slightly warm thermal sensation during the afternoon and late afternoon hours. This shows that people in tropical climate, especially in naturally ventilated building, can still tolerate the slightly warm indoor thermal condition. However, if given option, they would require for a cooler indoor environment.

The design of National University of Malaysia's mosque has certain characters that have good response to the tropical climate of Malaysia such as verandas that reduce the penetration of direct solar radiation and rainwater into the prayer halls. The application of glass walls all around, which allow ample permeability of daylight into the prayer halls, is also acceptable due to the presence of verandas. In addition, there are also abundant openings all around that allow for natural cross ventilation to occur. However, the increase of indoor operative temperature throughout the day might be due to the application of high thermal mass materials such as concrete and brick. Though the usage of low thermal mass materials such as timber and bamboo are more appropriate for tropical climate, they are less practical for a high volume mosque, with many floor levels.

Improvement should also be made to the design by providing openings at the dome area, in allowing the stack effect ventilation to occur. Nevertheless, consideration should also be made in preventing the rainwater to penetrate through the openings due to the high precipitation in tropical climate. In addition, innovation should also be made to the current openings in achieving higher indoor air velocity, which can enhance the indoor thermal comfort. Basically, the design of the mosque should be improved to achieve the indoor thermal comfort in tropical climate, especially during the afternoon and late afternoon hours.

This study provides guidance in designing a modern mosque in tropical climate that is able to provide indoor thermal comfort for the users. Nevertheless, this study shouldn't be stopped here as there are many other potential aspects to be explored in the future research related to the indoor thermal comfort of mosque. Such potential studies are the effect of various roof configurations to the indoor thermal comfort, the ratio of prayer hall area to the height, the mosque building materials and many others.

\section{ACKNOWLEDGEMENTS/NOTES}

A great gratitude is extended to National University of Malaysia (UKM) and Ministry of Education Malaysia for the research grant GUP-2019-017 and FRGS /1/2019/ TK10/UKM /02/4, respectively. The author would also like to thank the management of National University of Malaysia's mosque, and Nurul Huda Al-Ameen who had assisted the execution of the field measurement and questionnaire survey.

\section{CONFLICT OF INTEREST}

No conflict of interest was declared by the authors. 


\section{FINANCIAL DISCLOSURE}

The author declared that this study has received financial support from National University of Malaysia (UKM) and Ministry of Education Malaysia for the research grant GUP-2019-017 and FRGS /1/2019/ TK10/UKM /02/4, respectively.

\section{ETHICS COMMITTEE APPROVAL}

Ethics committee approval is not required for this article.

\section{LEGAL PUBLIC/PRIVATE PERMISSIONS}

In this research, the necessary permissions were obtained from the management of National University of Malaysia's mosque for the field measurement, and the respondents who participated in the questionnaire survey.

\section{REFERENCES}

Abdullah, F. H., Majid, N. H. A., \& Othman, R. (2016). Defining Issue of Thermal Comfort Control through Urban Mosque Façade Design. Procedia - Social and Behavioral Sciences, 234, 416 - 423.

Ahmad, A. A. (2015). Ruang dalaman masjid Melayu tradisional Semenanjung Malaysia. Universiti Malaya.

Al-ajmi, F. F. (2010). Thermal comfort in air-conditioned mosques in the dry desert climate. Building and Environment, 45, 2407-2413.

Al-Homoud, M. S., Abdou, A. A., \& Budaiwi, I. M. (2009). Assessment of monitored energy use and thermal comfort conditions in mosques in hothumid climates. Energy and Buildings, 41(6), 607-614.

Amir, A., Mohamed, M. F., Sulaiman, M. K. A. M., \& Yusoff, W. F. M. (2019). Assessment of indoor thermal condition of a low-cost single storey detached house: A case study in Malaysia. International Journal of Sustainable Tropical Design Research and Practice, 12(1), 80-88.

ASHRAE. (2017). ANSI/ASHRAE Standard 55-2017: Thermal Environmental Conditions For Human Occupancy. Atlanta.

Atmaca, A. B., \& Gedik, G. Z. (2020). Determination of thermal comfort of religious buildings by measurement and survey methods: Examples of mosques in a temperate-humid climate. Journal of Building Engineering, 30, 101246.

Azmi, N. A., \& Ibrahim, S. H. (2020). A comprehensive review on thermal performance and envelope thermal design of mosque buildings. Building and Environment, 185, 107305.

Azmi, N. A., \& Kandar, M. Z. (2019). Factors contributing in the design of environmentally sustainable mosques. Journal of Building Engineering, $23,27-37$.

Caetano, D. S., Kalz, D. E., Lomardo, L. L. B., \& Rosa, L. P. (2017). Evaluation of thermal comfort and occupant satisfaction in office buildings in hot and humid climate regions by means of field surveys. Energy Procedia, 115, 183-194.

Cândido, C., de Dear, R., \& Lamberts, R. (2011). Combined thermal 
acceptability and air movement assessments in a hot humid climate. Building and Environment, 46, 379-385.

Carlucci, S., Bai, L., de Dear, R., \& Yang, L. (2018). Review of adaptive thermal comfort models in built environmental regulatory documents. Building and Environment, 137, 73-89.

Chaiyapinunt, S., \& Khamporn, N. (2021). Effect of solar radiation on human thermal comfort in a tropical climate. Indoor and Built Environment, 30(3), 391-410.

Daghigh, R. (2015). Assessing the thermal comfort and ventilation in Malaysia and the surrounding regions. Renewable and Sustainable Energy Reviews, 48, 681-691.

Das, M., Das, A., \& Mandal, S. (2020). Outdoor thermal comfort in different settings of a tropical planning region: A study on Sriniketan-Santiniketan Planning Area (SSPA), Eastern India. Sustainable Cities and Society, 63, 102433.

Djamila, H., Chu, C. M., \& Kumaresan, S. (2013). Field study of thermal comfort in residential buildings in the equatorial hot-humid climate of Malaysia. Building and Environment, 62, 133-142.

Faghih, A. K., \& Bahadori, M. N. (2011). Thermal performance evaluation of domed roofs. Energy and Buildings, 43, 1254-1263.

Farhan, S. A., Ismail, F. I., Kiwan, O., Shafiq, N., Zain-Ahmed, A., Hamid, N. H., \& Abd, A. I. (2021). Effect of Roof Tile Colour on Heat Conduction Transfer, Roof-Top Surface Temperature and Cooling Load in Modern Residential Buildings under the Tropical Climate of Malaysia. Sustainability, 13, 4665.

Gagliano, A., Patania, F., Nocera, F., Ferlito, A., \& Galesi, A. (2012). Thermal performance of ventilated roofs during summer period. Energy and Buildings, 49, 611-618.

Guevara, G., Soriano, G., \& Mino-Rodriguez, I. (2021). Thermal comfort in university classrooms: An experimental study in the tropics. Building and Environment, 187, 107430.

He, Y., Liu, M., Kvan, T., \& Peng, S. (2017). An enthalpy-based energy savings estimation method targeting thermal comfort level in naturally ventilated buildings in hot-humid summer zones. Applied Energy, 187, 717-31.

Hoseini, A. hosein G., Berardi, U., Hoseini, A. G., \& Al-Obaidi, K. (2019). Analyzing the thermal comfort conditions of outdoor spaces in a university campus in Kuala Lumpur, Malaysia. Science of the Total Environment, 666, 1327-1345.

Hussin, A., Salleh, E., Chan, H. Y., \& Mat, S. (2015). The reliability of Predicted Mean Vote model predictions in an air-conditioned mosque during daily prayer times in Malaysia. Architectural Science Review, 58(1), 67-76.

Hwang, R. L., Lin, T. P., \& Kuo, N. J. (2006). Field experiments on thermal comfort in campus classrooms in Taiwan. Energy and Buildings, 38(1), 53-62.

Jayasinghe, M. T. R., Attalage, R. A., \& Jayawardena, A. I. (2003). Roof 
orientation, roofing materials and roof surface colour: their influence on indoor thermal comfort in warm humid climates. Energy for Sustainable Development, 7(1), 16-27.

Kiki, G., Kouchad'e, C., Houngan, A., Zannou-Tchoko, S. J., \& Andr'e, P. (2020). Evaluation of thermal comfort in an office building in the humid tropical climate of Benin. Building and Environment, 185, 107277.

Latha, P., Darshana, Y., \& Venugopal, V. (2015). Role of building material in thermal comfort in tropical climates-A review. Journal of Building Engineering, 3, 104-113.

López-Pérez, L. A., Flores-Prieto, J. J., \& Ríos-Rojas, C. (2019). Adaptive thermal comfort model for educational buildings in a hot-humid climate. Building and Environment (Vol. 150). Elsevier Ltd.

Mallick, F. H. (1996). Thermal comfort and building design in the tropical climates. Energy and Buildings, 23, 161-167.

Manaf, M. Z. A., Mohamed, M. F., Yusoff, W. F. M., \& Sulaiman, M. K. A. M. (2020). A Study On The Thermal Comfort Of Prayer Hall Based On The Roof Design Of Mosque With Natural Ventilation. International Journal of Advanced Science and Technology, 29(9), 1900-1915.

Munir, F. F. A., Tharim, A. H. A., Ahmad, A. C., Ismail, N., \& Jaafar, N. (2020). Association between thermal comfort condition and worshippers' satisfaction in timber and concrete of suburban religious buildings. Geographia Technica, 15, 53-63.

Rasdi, M. T. H. M., \& Mursib, G. (2004). Sahutan Regionalisme dalam Identiti Senibina di Malaysia: Adaptasi Awal Tradisi Modenisme 19501980. Jurnal Alam Bina, 6(2), 29-49.

Rodriguez, C. M., \& D'Alessandro, M. (2019). Indoor thermal comfort review: The tropics as the next frontier. Urban Climate, 29, 100488.

Saeed, S. A. R. (1996). Thermal comfort requirements in hot dry regions with special reference to Riyadh Part 2: For Friday prayer. International Journal of Ambient Energy, 17(1), 17-21.

Schaik, C. P. Van, \& Pfannes, K. R. (2005). Tropical climates and phenology: a primate perspective. In D. K. Brockman \& C. P. Van Schaik (Eds.), Seasonality in Primates: Study of Living and Extinct Human and Non-Human Primates (pp. 23-54). Cambridge University Press.

Tjie, C., Lianto, F., \& Priyomarsono, N. W. (2020). Climate Responsive Architecture in Jakarta's Apartments. IOP Conference Series Materials Science and Engineering, 852, 012150.

Toe, D. H. C., \& Kubota, T. (2013). Development of an adaptive thermal comfort equation for naturally ventilated buildings in hot-humid climates using ASHRAE RP-884 database. Frontiers of Architectural Research, 2(3), 278-291.

Tong, S., Wen, J., Wong, N. H., \& Tan, E. (2021). Impact of façade design on indoor air temperatures and cooling loads in residential buildings in the tropical climate. Energy and Buildings, 243, 110972.

Wang, Z., Dear, R. de, Luo, M., Lin, B., He, Y., Ghahramani, A., \& Zhu, Y. (2018). Individual difference in thermal comfort: A literature review. Building and Environment, 138, 181-193. 
Wijewardanea, S., \& Jayasinghe, M. T. R. (2008). Thermal comfort temperature range for factory workers in warm humid tropical climates. Renewable Energy, 33, 2057-2063.

Wong, N. H., Feriadi, H., Lim, P. Y., Tham, K. W., Sekhar, C., \& Cheong, K. W. (2002). Thermal comfort evaluation of naturally ventilated public housing in Singapore. Building and Environment, 37, 1267 - 1277.

Xue, F., \& Lau, S. S. Y. (2016). Climate-adaptive Urban Open Space Design Strategy in Workplace for Comfort and Health----Case in Hong Kong and Singapore. Procedia Engineering, 169, 332 - 339.

Yüksel, A., Arıcı, M., Krajčík, M., \& Karabay, H. (2020). Experimental investigation of thermal comfort and CO2concentration in mosques: A case study in warm temperate climate of Yalova, Turkey. Sustainable Cities and Society, 52, 101809.

Yusoff, W. F. M. (2020a). Initial assessment of indoor environmental condition and thermal comfort of Malaysia heritage mosque. Jurnal Kejuruteraan, 32(2), 271-280.

Yusoff, W. F. M. (2020b). The effects of various opening sizes and configurations to air flow dispersion and velocity in cross-ventilated building. Jurnal Teknologi, 82(4), 17-28.

\section{Resume}

Wardah Fatimah Mohammad Yusoff received her Bachelor of Architecture from International Islamic University of Malaysia, MSc in Environmental Design of Building from Cardiff University and Doctor of Philosophy in Architecture from University Putra Malaysia. She currently works as a senior lecturer at Universiti Kebangsaan Malaysia. Her expertise is in the field of natural ventilation and thermal comfort in buildings. 